\title{
Blue Jay Briefs
}

BIG RIVER, January 30.--Each year the number of birds seems to increase. They are a never-ending source of interest and, sometimes, amusement. There are three Canada Jays here every day (only one last winter) and they are quite tame. A few days ago, three Pine Grosbeaks appeared at the feeding station and now their number has increased to eight. They are such beautiful birds and their colorful plumage brightens the drab winter scene.

-Mrs. S. Olson

SANFORD, Man.-I have a bird box and many birds feed here all winter. There are four or five different kinds. Each night a Flying Squirrel comes and eats at the box. Last year I was caught out in the rain and as I neared the house I looked up to see how our old Robin was doing, as she was nesting on a low elm just behind the house. She was sitting on her nest and Mr. Robin was sitting on the edge with his wings spread out over her, just like an umbrella. 'She was nice and dry but he looked pretty beoraggled and sat blinking the rain from his eyes. What is home without the daddy!

-Mrs. Clara Parker

TULLIS.-In the last issue of the "Blue Jay," Mr. Ward asked about the Black-billed Cuckoo. I have only one record of them, in 1939. They nested in July in one of the poorest nests I've ever seen. I think they raised only one of the two eggs they laid. Once you have heard their call-it certainly is no song-you can never forget it. Where can I get information about birdbanding?

Write Fred G. Bard, Director of the Provincial Museum, Regina, Sask. -Mrs. C. E. Boon

PONOKA, Alta.-Was in a house at Red Deer when the first snow fell, and a Hummingbird came up to the nasturtiums in the window box. The hum was like that of a motor running, and not until ii moved to the next window was I sure it was the bird.

-C. H. Grant

BLADWORTH.-On October 26 I watched about twenty swans on the Arm River. This body of water is in the community pasture-so there is no shooting there. It's really surprising how the ducks and swans take advantage of it. As these were the first Swans I've ever watched, I didn't know what to look for to distinguish them as a Trumpeter or Whistler. They were magnificant birds. (The Trumpeter Swan is no longer found in Saskatchewan. Now only a few small flocks are known in British Columbia and Alberta. Strenuous efforts are now being made to preserve the last remaining individuals of this beautiful species. Ed.)

-P. Lawrence Becky

SKULL CREEK.-This is the first year since 1913 that I have not seen at least a few. Horned Larks staying with with us for the winter. There haven't been any since late November; nor have I seen or heard Great Horned Owls, but a neighbour six miles south of here told me that he had seen one several times during December. There were a great number of Bohemian Waxwings around during the winter, seen in flocks of from ten to fifteen to the large one I saw around Christmas of from 450 to 500. Earlier in the season I saw several fairly large flocks of Pine Grosbeaks, but no Evening Grosbeaks which usually appear with them. 